\title{
PENGEMBANGAN MEDIA STORY TELLING BERBASIS MONTASE SEDERHANA SEBAGAI SUPLEMEN BAHAN AJAR TEMA PEDULI TERHADAP MAKHLUK HIDUP KELAS IV SEKOLAH DASAR
}

\author{
Himmatul Ulya ${ }^{1}$, Rofian ${ }^{2}$ \\ himmatululya28@gmail.com ${ }^{1}$ \\ PGSD, FIP, Universitas PGRI Semarang ${ }^{12}$
}

\begin{abstract}
Abstrak: Latar belakang yang mendorong dalam penelitian ini adalah kurangnya media pembelajaran tematik yang melibatkan kreativitas siswa dan pendukung kegiatan literasi sekolah sebagai sumber bahan belajar siswa. Adapun tujuan penelitian untuk mengetahui kelayakan media story telling berbasis montase sederhana sebagai suplemen bahan ajar tema Peduli Terhadap Makhluk Hidup kelas IV Sekolah Dasar. Jenis penelitian yang digunakan ialah Research and Development (RnD) dengan model pemikiran Borg and Gall. Teknik analisis data menggunakan deskriptif kualitatif dan deskriptif kuantitatif. Hasil kelayakan berdasarkan analisis data oleh pakar ahli memperoleh rata-rata presentase sebesar 92,46\% untuk kelayakan media dan 91,31\% untuk kelayakan materi pembelajaran. Perolehan respon guru terhadap keberterimaan media memperoleh presentase di SD Negeri Mranggen 01 sebesar 95,58\%, SD Negeri Mranggen 02 sebesar 88,25\% dan SD Negeri Mranggen 04 memperoleh presentase sebesar 91,17\% Hasil angket respon siswa memperoleh 90,64\% di SD Negeri Mranggen 01, 93,21\% di SD Negeri Mranggen 02 dan 85,36\% di SD Negeri Mranggen 04. Media story telling berbasis montase sederhana sebagai suplemen bahan ajar tema peduli terhadap makhluk hidup telah memenuhi kriteria sangat baik dan layak untuk digunakan dalam proses pembelajaran.
\end{abstract}

Kata kunci: pengembangan, media, story telling, montase, bahan ajar

\section{DEVELOPMNET OF STORY TELLING MEDIA BASED SIMPLE MONTAGE FOR SUPPLEMENT TEACHING MATERIALS THEME PEDULI TERHADAP MAKHLUK HIDUP CLASS IV ELEMENTARY SCHOOL}

\begin{abstract}
The background that encourage of this study is the lack of thematic learning media involving student creativity and supporting school literacy activities as a source of student learning materials. The purpose of the study to determine the feasibility of a simple story-based media story telling as a supplement of teaching materials theme of Care Against 4th grade elementary school. The type of research used is Research and
\end{abstract}


Himmatul, Rofian, Pengembangan Media Story Telling...

Development $(\mathrm{RnD})$ with Borg and Gall thinking model. Data analysis techniques used descriptive qualitative and quantitative descriptive. The feasibility result based on data analysis by experts obtained the average percentage of $92.46 \%$ for media feasibility and $91.31 \%$ for the feasibility of learning materials. The acquisition of teacher response to media acceptance obtained percentage in SD Negeri Mranggen 01 equal to 95,58\%, SD Negeri Mranggen 02 equal to 88,25\% and SD Negeri Mranggen 04 got percentage equal to $91,17 \%$ Result questionnaire student response learn 90,64\% Elementary School of Mranggen 01, 93.21\% in SD Negeri Mranggen 02 and 85.36\% in SD Negeri Mranggen 04. Media story telling simple montage based as a supplement teaching materials subject to the theme of living beings have met the criteria very well and deserve to be used in learning process.

Keywords: development, media, story telling, montage, teaching materials

\section{PENDAHULUAN}

Seperti yang termuat dalam Undang-Undang Sistem Pendidikan Nasional No.20 tahun 2003 bahwa tujuan dari pendidikan nasional yaitu untuk mengembangkan potensi dalam diri siswa agar menjadi manusia yang beriman dan bertaqwa kepada Tuhan Yang Maha Esa, berakhlak mulia, berilmu, cakap, kreatif, mandiri, dan menjadi warganegara yang demokratif, serta bertanggung jawab. Potensi yang harus dikembangkan tersebut berupa kreativitas dan kemandirian. Munculnya kreativitas dan kemandirian pada diri siswa, diharapkan akan mampu berinovasi secara produktif dalam menghadapi tantangan abad-21 yang semakin kompleks.

Kreativitas individu, dapat diperoleh dari sebarapa banyak pengetahuan yang dimiliki sedengkan pengetahuan dapat diperoleh melalui kegiatan membaca. Peraturan Menteri Pendidikan dan Kebudayaan Nomor 23 Tahun 2015 tentang GLS sebagai salah satu upaya pemerintah untuk mendorong minat membaca siswa sehingga dapat merangsang munculnya imajinasi dalam otak agar menghasilkan gagasan dan berkarya.

Hasil studi Most Littered Nation In the World tahun 2016 bahwa minat baca di Indonesia masih tergolong rendah. Data yang diperoleh menunjukkan bahwa Indonesia menduduki peringkat 60 dari 61 negara. Pernyataan tersebut juga sejalan dengan hasil observasi peneliti di Sekolah Dasar Kecamatan Mranggen Kabupaten Demak yang meliputi SDN Mranggen 01, SDN Mranggen 02, dan SDN Mranggen 04. Hasil observasi menunjukkan bahwa pelaksanaan GLS masih belum terlaksana secara optimal. Kendala tersebut, disebabkan oleh kurangnya penyediaan sumber bahan bacaan bagi siswa. Selain itu, bahan bacaan hanya berupa buku pelajaran yang berdampak pada rendahnya minat membaca siswa. Kebanyakan bahan bacaan yang dijumpai oleh siswa hanya mengacu pada bacaan berupa dongeng, legenda, mitos dan fabel. Kurangnya bahan bacaan yang memuat materi pada bahan ajar dan kreativitas siswa dalam berkarya seni mengakibatkan menurunnya kemandiran siswa dalam belajar 
Himmatul, Rofian, Pengembangan Media Story Telling....

dan berkreatifitas karya seni. Hal ini sejalan dengan pengamatan pada tema Peduli Terhadap Makhluk Hidup pada ketrampilan berkarya seni montase.

Seni montase merupakan kajian seni budaya dan prakarya yaitu seni rupa dua dimensi yang sangat identik dengan kegiatan memotong gambar lalu menempelkannya (Muharrar, 2013 : 44). Dikatakan dengan seni montase sederhana disebabkan menggunakan penempelan gambar yang dilakukan secara sederhana tanpa melibatkan unsur benda lainnya. Alasan mendasar belum adanya media pembelajaran tematik sebagai penguasaan konsep pengetahuan dan ketrampilan mengakibatkan siswa kurang antusias dalam mengikuti proses pembelajaran. Arsyad (2014:29) manfaat dari media pembelajaran tidak hanya sebagai penyampaian informasi namun juga dapat meningkatkan dan mengarahkan perhatian siswa sehingga menimbulkan motivasi belajar, interaksi siswa yang berdampak pada kemandirian belajar siswa yang sesuai dengan kemampuan dan minatnya. Keterlibatan penggunaan media dalam proses pembelajaran merupakan upaya untuk menciptakan pengalaman belajar yang bermakna bagi siswa khusus pada pengimplementasian kurikulum 2013 yang sangat identik dengan pembelajaran tematik. Rusman (2015:227) salah satu kesuksesan dalam pengimplementasian kurikulum 2013 berupa penggunaan media yang bervariatif untuk dapat membentuk kompetensi peserta didik. Pembelajaran tematik tidak hanya melibatkan tema untuk mengaitkan beberapa mata pelajaran, melainkan juga melibatkan siswa dalam proses pelaksanaan pembelajaran. Hal ini sesuai dengan pandanan Prastowo (2014:56) tematik merupakan suatu model dengan pendekatan tematik dengan keterlibatan siswa secara aktif dan menyenangkan yang tidak semata-mata siswa untuk mengetahui, melainkan juga learning to do, learning to be, dan learning to live together.

Teori Jean Piaget dalam Dahar (2011:138) menyatakan bahwa anak usia sekolah dasar (7-11 tahun) dalam tingkatan operasional konkret, dimana tingkatan ini merupakan permulaan dalam berfikir secara rasional. Dengan demikian, sumber belajar baik yang berupa bahan ajar atau media pada jenjang Sekolah Dasar hendaknya ditekankan pada gambar atau benda-benda konkret yang dapat menunjang kemampuan intelektual dan kemampuan literasi. Buku merupakan bagian terpenting yang perlu disediakan untuk keberlangsungan proses pembelajaran. Menurut Daryanto (2016:26) bahwa buku termasuk media pembelajaran visual dengan penyajian secara cetak, sedangkan pandangan Prastowo (2015: 17-24) buku merupakan salah satu dari bahan ajar. Bahan ajar diartikan segala bahan yang dikuasai dalam proses pembelajaran maupun dalam meningkatkan ketrampilan yang disusun secara sistematis.

Penyajian produk media berupa buku cetak dengan penggunaan secara story telling yaitu dengan melibatkan cerita dalam penyampaian materi pembelajaran. Cerita merupakan bentuk sastra yang disampaikan oleh pembicara dan pendengar (Musifiroh, 2008:81-89) Menurut penelitian Wardiah (2017) bahwa kegiatan story telling memiliki peranan dalam meningkatkan kemampuan literasi siswa yang meliputi menulis, membaca, dan emosional siswa. Hal tersebut juga didukung oleh penelitian Miller, Sara 
Himmatul, Rofian, Pengembangan Media Story Telling...

and Lisa Pennycuff (2008: 39) yang menjelaskan bahwa story telling dapat menjadi teknik yang efektif untuk mengembangkan kemampuan literasi dan menarik perhatian siswa dalam meningkatkan minat membaca.

Berdasarkan uraian permasalahan diatas, belum banyaknya media pembelejaran berupa buku cerita dengan melibatkan kreativitas siswa maka peneliti berinovasi untuk mengembangkan produk media pembelajaran tematik dengan melibatkan adanya kreativitas siswa dalam berkarya seni montase dan dapat mendukung kegiatan pelaksanaan literasi siswa. Maka dilakukannya penelitian pengembangan media storytelling berbasis montase sebagai bahan ajar tema peduli terhadap makhluk pada kelas IV Sekolah Dasar.

Tujuan Penelitian ini ialah untuk mengetahui kelayakan dari produk media story telling berbasis montase sederhana sebagai suplemen bahan ajar tema peduli terhadap makhluk hidup kelas IV Sekolah Dasar.

\section{METODE}

Metode penelitian yang digunakan yaitu Research and Development. Menurut pandangan Sugiyono (2016: 30) penelitian dan pengembangan (research and Development) adalah dapat diartikan sebagai cara ilmiah untuk meneliti, merancang, memproduksi, da menguji validitas produk yang telah dihasilkan. Model yang digunakan ialah menurut tahapan penelitian yang dikemukakan oleh Borg ang Gall yang terdiri dari 10 tahapan (Sugiyono,2016: 35-36). Berdasarkan pedoman skripsi S1 Univesitas PGRI Semarang pada penelitian dan pengembangan hanya dilakukan sampai pada tahapan ke-5 yang meliputi Research and Information Collecting, Planning, Development Preliminary Form a Product, Development Preliminary Form a Product, and Main Product Revision. Uji kelayakan mengenai pengembangan produk media story telling berbasis montase sederhana dilakukana dengan pemberian kuisoner (anngket) mengenai kelayakan media dan materi pembelejaran oleh validator Dosen ahli, kuisoner (angket) respon siswa dan guru untuk keberteriman media pada tahap uji coba lapangan.

Uji coba lapangan dilakukan di 3 Sekolah Dasar yang berada di lingkup Kecamatan Mranggen Kabupaten Demak Provinsi Jawa Tengah yang meliputi SD Negeri Mranggen 01 dengan sampel 26 siswa, SD Negeri Mranggen 02 dengan sampel 28 siswa, dan SD Negeri Mranggen 04 dengan sampel 23 siswa yang dilakukan pada tanggal 10-16 April 2018. Tahapan uji coba lapangan dilakukan apabila produk media yang dikembangkan telah dinyatakan layak oleh validator Dosen ahli. Teknik pengumpulan data yang dilakukan oleh peneliti berupa data kualitatif dan data kuantitaif sebagi berikut:

Tabel 1. Teknik Pengumpulan Data

\begin{tabular}{|l|l|l|l|l|l|}
\hline No. & Data & Teknik & Waktu & Sasaran & Tujuan \\
\hline
\end{tabular}


Himmatul, Rofian, Pengembangan Media Story Telling...

\begin{tabular}{|l|l|l|l|l|l|}
\hline \hline 1. & Kualitatif & Wawancara & Studi pendahuluan & Guru Kelas IV & $\begin{array}{l}\text { Untuk } \\
\text { mengetahui } \\
\text { potensi dan } \\
\text { masalah }\end{array}$ \\
\hline 2. & Kuantitatif & Angket & $\begin{array}{l}\text { Studi pengembangan } \\
\text { dan pada tahap uji } \\
\text { coba pengembangan } \\
\text { produk }\end{array}$ & $\begin{array}{l}\text { Ahil media, ahli } \\
\text { materi guru } \\
\text { dan siswa kelas } \\
\text { IV }\end{array}$ & $\begin{array}{l}\text { Untuk } \\
\text { mengetahui } \\
\text { kelayakan } \\
\text { produk media }\end{array}$ \\
\hline
\end{tabular}

Perolehan analisis data dilakukan secara deskriptif kualitatif dan disktriptif kuantatif. Skor penilaian kuesioner menggunakan skala Likert pada kusioner instrumen validasi dan keberterimaan media. Sedangkan, skala Guttaman diberikan pada kuesioner respon siswa. Skala Guttaman hanya menghadirkan sejumlah pertanyaan berupa positf (1) dan negatif (0) dalam suatu obyek sedangkan skala Likert yaitu dengan menghadirkan pilihan jawaban melalui skor nilai meliputi "4(sangat baik), 3(baik), 2(cukup) dan 1 (kurang)." Perhitungan presentase kelayakan dari hasil analisis data dilakukan dengan acuan rumus yang dikemukakan oleh Tegeh dan Kirna, 2010:101 dalam Praditya (2017) yaitu dengan cara Presentase $(\%)=\frac{\text { Jumlah Skor Total }(x)}{\text { Jumlah Skor Maximum (xi) }} \mathrm{x}$ $100 \%$

Untuk mengetahui penilaian kelayakan produk pengembangan maka dibutuhkan intrepretasi kriteria penilaian. Dalam hal ini menggunakan nilai presentase yang dikemukakan oleh Arikunto (2010:44) sebagai kriteria penilaian kelayakan pada tabel dibawah ini:

Tabel 2. Kriteria Penilaian Kelayakan Produk

\begin{tabular}{|l|l|}
\hline Interpretasi & Kriteria \\
\hline $\mathbf{8 1 \% - 1 0 0 \%}$ & Sangat Baik \\
\hline $\mathbf{6 1 \% - 4 0 \%}$ & Baik \\
\hline $\mathbf{4 1 \% - 6 0 \%}$ & Cukup \\
\hline $\mathbf{2 1 \% - 8 0 \%}$ & Kurang \\
\hline $\mathbf{0 \% - 2 0 \%}$ & Sangat Kurang \\
\hline
\end{tabular}

\section{HASIL}

Uji kelayakan produk media story telling berbasis montase sederhana divalidator oleh 3 Dosen ahli media dan materi pembelejaran. Tahapan ini dilakukan untuk mengetahui kelayakan media story telling berbasis montase sederhana sebelum digunakan pada tahap uji coba lapangan yang bertujuan untuk mengetahui respon penggunaan media pada proses pembelejaraan. Perolehan validasi kelayakan media dan materi dapat dilihat pada tabel berikut ini:

Tabel 3. Kelayakan Media

\begin{tabular}{|l|l|l|l|l|l|}
\hline \multirow{2}{*}{ No } & Aspek & \multicolumn{4}{|l|}{ Penilaian Validasi } \\
\cline { 2 - 5 } & Kriteria & Media 1 Tahap 1 & Media 2 Tahap I & Media 2 Tahap II & Media 3 Tahap I \\
\hline 1. & Psikologis & $87,50 \%$ & $62,50 \%$ & $87,50 \%$ & $81,25 \%$ \\
\hline
\end{tabular}


Himmatul, Rofian, Pengembangan Media Story Telling....

\begin{tabular}{|l|l|l|l|l|l|}
\hline \multirow{2}{*}{ No } & Aspek & Kenilaian Validasi & \multicolumn{5}{l|}{} \\
\cline { 2 - 6 } & Kriteria & Media 1 Tahap 1 & Media 2 Tahap I & Media 2 Tahap II & Media 3 Tahap I \\
\hline 2. & Organisasi Isi & $95,83 \%$ & $58,33 \%$ & $87,50 \%$ & $91,67 \%$ \\
\hline 3. & Penyajian & $100,00 \%$ & $56,25 \%$ & $87,50 \%$ & $100,00 \%$ \\
\hline 4. & Penggunaan Media & $100,00 \%$ & $50,00 \%$ & $91,67 \%$ & $100,00 \%$ \\
\hline 5. & Elemen cetak & $95,83 \%$ & $41,67 \%$ & $91,67 \%$ & $91,67 \%$ \\
\hline 6. & Prinsip Visual & $100,00 \%$ & $50,00 \%$ & $90,00 \%$ & $85,00 \%$ \\
\hline Kriteria & Sangat Baik & Cukup Baik & Sangat Baik & Sangat Baik \\
\hline
\end{tabular}

Tabel 4. Kelayakan Materi

\begin{tabular}{|l|l|l|l|l|l|}
\hline \multirow{2}{*}{ No } & Aspek & Penilaian Validasi & \multicolumn{2}{l|}{} \\
\cline { 2 - 5 } & Kriteria & Media 1 Tahap 1 & Media 2 Tahap I & Media 2 Tahap II & Media 3 Tahap I \\
\hline 1. & $\begin{array}{l}\text { Indikator } \\
\text { Kesesuaian }\end{array}$ & $93,75 \%$ & $43,75 \%$ & $87,50 \%$ & $87,50 \%$ \\
\hline 2. & Penyajian isi & $95,00 \%$ & $52,50 \%$ & $90,00 \%$ & $95,00 \%$ \\
\hline 3. & Kebahasaan & $91,67 \%$ & $50,00 \%$ & $87,50 \%$ & $83,30 \%$ \\
\hline 4. & Kompetensi & $93,75 \%$ & $50,00 \%$ & $93,75 \%$ & $93,75 \%$ \\
\hline Kriteria & Sangat Baik & Cukup Baik & Sangat Baik & Sangat Baik \\
\hline
\end{tabular}

Tabel 5. Keberterimaan Media Guru Kelas

\begin{tabular}{|l|l|l|l|}
\hline No. & Sekolah & Skor Penilaian & Kriteria \\
\hline 1. & SDN Mranggen 01 & $95,58 \%$ & Sangat baik \\
\hline 2. & SDN Mranggen 02 & $88,25 \%$ & Sangat baik \\
\hline 3. & SDN Mranggen 04 & $91,17 \%$ & Sangat baik \\
\hline
\end{tabular}

Tabel 6. Respon Ssiswa SDN Mranggen 01

\begin{tabular}{|l|l|l|l|}
\hline Kode & Skor & Kode & Skor \\
\hline S-1 & 27 & S-15 & 29 \\
\hline S-2 & 30 & S-16 & 20 \\
\hline S-3 & 30 & S-17 & 20 \\
\hline S-4 & 27 & S-18 & 27 \\
\hline S-5 & 25 & S-19 & 30 \\
\hline S-6 & 20 & S-20 & 25 \\
\hline S-7 & 29 & S-21 & 29 \\
\hline S-8 & - & S-22 & 25 \\
\hline S-9 & 30 & S-23 & 29 \\
\hline S-10 & 30 & S-24 & 30 \\
\hline S-11 & 25 & S-25 & 30 \\
\hline S-12 & 25 & S-26 & 30 \\
\hline S-13 & 25 & S-27 & 30 \\
\hline S-14 & 30 & & \\
\hline Perhitungan Nilai Presentase total: $90,64 \%$ & \\
\hline
\end{tabular}

Tabel 7. Respon Siswa SDN Mranggen 02

\begin{tabular}{|l|l|l|l|}
\hline Kode & Skor & Kode & Skor \\
\hline S-1 & - & S-16 & 26 \\
\hline S-2 & 20 & S-17 & 27 \\
\hline S-3 & 27 & S-18 & 26 \\
\hline S-4 & 25 & S-19 & 30 \\
\hline S-5 & 25 & S-20 & - \\
\hline S-6 & 25 & S-21 & 26 \\
\hline S-7 & 28 & S-22 & 29 \\
\hline S-8 & 27 & S-23 & 30 \\
\hline S-9 & 27 & S-24 & 29 \\
\hline
\end{tabular}


Himmatul, Rofian, Pengembangan Media Story Telling...

\begin{tabular}{|l|l|l|l|}
\hline Kode & Skor & Kode & Skor \\
\hline S-10 & 27 & S-25 & 28 \\
\hline S-11 & 30 & S-26 & 28 \\
\hline S-12 & 30 & S-27 & 28 \\
\hline S-13 & 28 & S-28 & 30 \\
\hline S-14 & 30 & S-29 & 30 \\
\hline S-15 & 30 & S-30 & 30 \\
\hline \multicolumn{2}{|l|}{ Perhitungan Nilai Presentase total: $93,21 \%$} \\
\hline
\end{tabular}

Tabel 8. Respon Siswa SDN Mranggen 04

\begin{tabular}{|l|l|l|l|}
\hline Kode & Skor & Kode & Skor \\
\hline S-1 & - & S-15 & - \\
\hline S-2 & 30 & S-16 & 25 \\
\hline S-3 & 26 & S-17 & - \\
\hline S-4 & 27 & S-18 & 28 \\
\hline S-5 & 25 & S-19 & - \\
\hline S-6 & 27 & S-20 & 27 \\
\hline S-7 & 27 & S-21 & 30 \\
\hline S-8 & 19 & S-22 & 30 \\
\hline S-9 & 28 & S-23 & 22 \\
\hline S-10 & 25 & S-24 & 30 \\
\hline S-11 & 24 & S-25 & 27 \\
\hline S-12 & 30 & S-26 & 27 \\
\hline S-13 & 25 & S-27 & 25 \\
\hline S-14 & 27 & \\
\hline Perhitungan Nilai Presentase total :85,36\% \\
\hline
\end{tabular}

\section{PEMBAHASAN}

Pengembangan media story telling berbasis montase sederhana merupakan suatu produk media berupa yang memuat cerita anak dengan mengintegrasikan materi secera tematik yang meliputi Bahasa Indonesia KD 3.1 memahami wawancara, IPA KD 34 menganalisis bagian dan fungsi tumbuhan dan SBdP KD 3.1 Memahami teknik menempel pada kajian tema peduli terhadap makhluk hidup kelas IV Sekolah Dasar. Bentuk kemasan buku menjadikan media story telling berbasis montase sederhana mudah disimpan, mudah dibawa kemanapun dan bahkan dapat dijadikan sebagai sumber kemandirian belajar siswa.

Uji kelayakan melibatkan 3 dosen ahli sesuai dengan kajian materi pada media story telling berbasis montase sederhana yaitu Dosen ahli Seni Rupa SD sebagai validator media 1 dan materi 1, Dosen Ahli Bahasa Indonesia SD sebagai validator media 2 dan materi 2, dan Dosen Ahli IPA SD sebagai validator media 3 dan materi 3. Analisis kelayakan media menggunakan kriteria pemilihian media yang dikemukakan oleh Arsyad, (2015:60-77) yang meliputi aspek psikologis, organisasi isi, penyajian, penggunaan, elemen cetak dan prisnip visual, sedangkan analisis kelayakan materi didasarkan pada BNSP 2016 Kurikulum 2013 yang dirangkum meliputi aspek indikator kesesuaian, penyajian, kebahasaan dan kompetensi. (BNSP: 2016).

Rumus perolehan uji kelayakan diperoleh dari penilaian masing -masing komponen yaitu dengan cara skor yang diperoleh dibagi dengan skor maksimal dan kemudian dikali $100 \%$. Perolehan nilai validasi kelayakan media 1 tahap I sebesar 
Himmatul, Rofian, Pengembangan Media Story Telling....

96,42\% dengan kriteria "sangat baik" tanpa revisi. Kelayakn media 2 tahap I memperoleh 52,67\% dengan kriteri "cukup baik" dengan syarat revis. Perbaikan produk media berdasarkan saran validator, maka dilakukan validasi media 2 tahap II sebesar 89,28\% dengan kriteria "sangat baik". Tahapan validasi media 3 tahap I memperoleh nilai presentase sebesar 91,64\% dengan kriteria "sangat baik". Uji kelayakan materi memperoleh nilai presentase 93,75\% dengan kriteraia "sangat baik" pada materi 1 tahap I, tahap matari 2 tahap I sebesar 50,00\% dengan krieria "cukup baik" dengan revisi maka dilanjutkan penilian materi 2 tahap II memperoleh nilai $89,58 \%$ dengan kriteria "sangat baik" dan validasi materi 3 tahap I mempereoleh nilai presentase 90,62\% dengan kriteria "sangat baik". Nilai validasi rata-rata media secara keseluruhan memperoleh $92,46 \%$ dengan kriteria "sangat baik" rata-rata validasi materi sebesar $91,31 \%$.

Media story telling berbasis montase sederhana memperoleh kriteria sangat layak pada tahap uji kelayakan maka dapat dilakukan tahapan uji coba lapangan yang dilakukan secara terbatas pada 3 Sekolah Dasar yang berada di lingkup Kecamatan Mranggen Kabupaten Demak. Uji coba lapangan dilakukan untuk mengetahui keberterimaan media pada penggunaan proses pembelajaran. Perolehan keberterimaan media oleh guru memperoleh nilai di SDN Mranggen 01 sebesar 95,58\% dengan kriteria "sangat baik", SDN Mranggen 02 memperoleh 88,25\% dengan kriteria "sangat baik", dan nilai validasi sebesar 91,17\% pada SDN Mranggen 04 dengan kriteria "sangat baik". Perolahan nilai presentase repson siswa terhadap penggunaan media story telling berbasis montase sederhana pada uji coba lapangan ialah sebesar 85,36\% di SDN Mranggen 04, 93,21\% di SDN Mranggen 02 dan perolehan nilai presentase 90,64\% untuk SDN Mranggen 01.

Keunggulan dari produk media tersebut terletak pada penggunaan media secara activity interactive yaitu dengan melibatkan siswa dalam penggunaan media pada proses pembelajaran. Pada ilustrasi gambar desian seni montase dilakukan secara sederhana yaitu dengan cara menempelkan gambar koleksi karya pribadi yang berasal dari gambar seni cair air yang ditempelkan secara manual tanpa melibatkan unsur benda lainya. Penyajian gambar secara montase sebagai ilustrasi pendukung cerita untuk memberikan presepsi pemahaman kepada siswa tentang cara teknik menempel gambar montase.

\section{SIMPULAN}

Media story tellng berbasis montase sederhana telah memenuhi kriteria kelayakan media dan materi pembelajaran. Hasil kelayakan produk media tersebut, diperoleh berdasarkan tahapan proses pengembangan oleh validator Dosen ahli dengan nilai 92,46\% untuk kelayakan media dan 91,31\% untuk kelayakaan materi pembelajaran. Perolehan keberterimaan media oleh guru memperoleh nilai di SDN Mranggen 01 sebesar 95,58\% dengan kriteria "sangat baik", SDN Mranggen 02 memperoleh 88,25\% dengan kriteria "sangat baik", dan nilai validasi sebesar 91,17\% pada SDN Mranggen 04 dengan kriteria "sangat baik". Perolahan nilai presentase repson siswa terhadap 
Himmatul, Rofian, Pengembangan Media Story Telling....

penggunaan media story telling berbasis montase sederhana pada uji coba lapangan ialah sebesar 85,36\% di SDN Mranggen 04, 93,21\% di SD Negeri Mranggen 02 dan perolehan nilai presentase 90,64\% untuk SDN Mranggen 01.

Perolehan nilai tersebut menunjukkan bahwa media story telling berbasis montase sederhana sangat baik dan layak untuk dijadikan sebagia pendamping bahan ajar utama pada tema peduli terhadap makhluk hidup kelas IV Sekolah Dasar. Penggunaan media story telling berbasis montase sederhana pada proses pembelajaran dapat memberikan kemudahan pemahaman materi secera mendalam, kemandirian belajar, meningkatkan keaktifan dan kreatifitas dalam berkarya seni montase

Saran yang diberikan untuk penelitian tahap selanjutnya ialah dibutuhkannya lembar diskusi siswa secara terpisah sebagai pendamping dari penggunaan media story telling berbasis montase sederhana.

\section{DAFTAR PUSTAKA}

Arikunto, S. 2010. Manajemen Penelitian. Jakarta: Rineka Cipta

Arsyad, A. 2015. Media Pembelajaran. Jakarta: PT Raja Grafindo Persada.

Daryanto. 2016. Media Pembelajaran Peranannya Sangat Penting Dalam Mencapai Tujuan Pembelajaran. Yogyakarta: Gava Media

Dahar, R. W. 2011. Teori-teori Belajar dan Pembelajaran. Jakarta: Erlangga

Miller, S., \& Pennycuff, L. (2008). The power of story: Using storytelling to improve literacy learning. Journal of Cross-Disciplinary Perspectives in Education, 1(1), 36-43. http://www.mihantarjomeh.com/wp-content/uploads/2015/02/gfdsgThePowerder-dsgdfghof______zs.pdf. Diakses tanggal 5 November 2017

Muharrar, S. 2013. Kreasi Kolase, Montase dan Mozaik Sederhana. Jakarta: Erlangga

Praditya, M. A., Parmiti, D. P., \& Tastra, I. D. K. (2017). Pengembangan Buku Cerita Elektronik Dengan Metode Story Telling Pada Mata Pelajaran Bahasa Indonesia Kelas Ii Semester Genap Tahun Pelajaran 2016/2017 Di Sd Negeri 4 Banyuning. Jurnal Edutech Undiksha, 8(2). https://ejournal.undiksha.ac.id/index.php/JJTP/article/view/11938 • Diakses tanggal 5 Oktober 2017.

Peraturan Menteri Pendidikan dan Kebudayaan Republik Indonesia Nomor 57 Tahun 2014 tentang Kurikulum Pendidikan SD/MI

Peraturan Menteri Pendidikan dan Kebudayaan Republik Indonesia Nomor 22 Tahun 2016 tentang Standar Proses Pendidikan SD/MI

Peraturan Menteri Pendidikan dan Kebudayaan Republik Indonesia Nomor 23 Tahun 2015 tentang Budi Pekerti

Prastowo, A. 2014. Pengembangan Bahan Ajar Tematik Tinjauan Teoritis dan Praktik. Jakarta: Kencana

Rusman. 2015. Pembelajaran Tematik Terpadu Teori, Praktik, dan Penilaian. Jakarta: Rajawali Pers. 
Himmatul, Rofian, Pengembangan Media Story Telling...

Sugiyono. 2016. Metode Penelitian \& Pengembangan (Research and Development). Bandung: Alfabeta

Wardiah, D. (2017). Peran Storytelling Dalam Meningkatkan Kemampuan Menulis, Minat Membaca Dan Kecerdasan Emosional Siswa. Wahana Didaktika, 15(2). http://univpgri-palembang.ac.id/e_jurnal/index.php/didaktika/article/view/1236/0. Diakses pada tanggal 22 maret 2018. 